\title{
Egalitarian challenges to global egalitarianism: a critique
}

\author{
CHRISTIAN BARRY AND LAURA VALENTINI*
}

\begin{abstract}
Many political theorists defend the view that egalitarian justice should extend from the domestic to the global arena. Despite its intuitive appeal, this 'global egalitarianism' has come under attack from different quarters. In this article, we focus on one particular set of challenges to this view: those advanced by domestic egalitarians. We consider seven types of challenges, each pointing to a specific disanalogy between domestic and global arenas which is said to justify the restriction of egalitarian justice to the former, and argue that none of them - both individually and jointly - offers a conclusive refutation of global egalitarianism.
\end{abstract}

\section{Introduction}

In recent decades, several political theorists have argued in favour of extending the scope of egalitarian principles of distributive justice from the domestic to the international arena. This view, which might be called 'global egalitarianism', is motivated by powerful ethical considerations.

Most of us share the conviction that people's life prospects should not be influenced - or at least not influenced unduly - by morally arbitrary factors, such as race, gender and place of birth. ${ }^{1}$ Despite this, in today's world, people's life prospects vary dramatically depending on whether they have been born in, say, Sub-Saharan Africa or Europe.

The ethical imperative of addressing such global inequalities appears all the more urgent once it is noticed that they are the product of human agency rather than a sheer matter of luck. Global inequalities are in large measure a social, not a natural fact: they depend on the combined effects of people's decisions and conduct over an extended period of time. The shape of our present international order, the institutions comprising it and the distribution of opportunities across its inhabitants, are the result of historical processes undeniably marked by a great deal of oppression and exploitation. ${ }^{2}$

\footnotetext{
* We are grateful to Pablo Gilabert, Robert Goodin, Iseult Honohan, Fiona Jenkins, Eszter Kollar, Cécile Laborde, Christian List, Gerhard Øverland, Matt Peterson, Thomas Pogge, Larry Temkin and Lea Ypi for very helpful comments on earlier versions of this article.

${ }^{1}$ Recent theoretical defences of this idea are offered by Simon Caney, Justice beyond Borders: A Global Political Theory (Oxford: Oxford University Press, 2005), Darrel Moellendorf, Cosmopolitan Justice (Boulder, CO: Westview Press, 2002) and Kok-Chor Tan, Justice without Borders: Cosmopolitanism, Nationalism and Patriotism (Cambridge: Cambridge University Press, 2004).

${ }^{2}$ This point is forcefully made by Thomas W. Pogge in World Poverty and Human Rights: Cosmopolitan Responsibilities and Reforms (Cambridge: Polity, 2002).
} 
Even more troublingly, the wealth enjoyed nowadays by the World's most advantaged seems to depend significantly on the hardships suffered by the least advantaged. The globally advantaged enjoy inexpensive (for them) goods and services very often produced by the poor and destitute, who are in turn excluded from their use. ${ }^{3}$

Despite their intuitive appeal, global egalitarian doctrines have long been subject to well-known and forceful criticisms. Readers of this journal will be familiar with traditional realist, libertarian and communitarian arguments against global equality: The first arguing that the international realm is a 'morality free' zone, ${ }^{4}$ the second accusing egalitarian distributive policies of infringing unduly on people's liberties, ${ }^{5}$ and the third questioning the existence of demanding crosscultural moral standards. ${ }^{6}$ And of course there are those who simply reject the value of economic and social equality as such. ${ }^{7}$

More recently, a fourth group of theorists have offered reasons to reject global egalitarianism. What makes this group particularly noteworthy is that it is made up of scholars who are neither sceptical about egalitarian demands as such, nor denigrate the idea of an international morality. On the contrary, some of them have made very important contributions to egalitarian thinking in the domestic arena and have even attempted to work out a moral theory of international relations. ${ }^{8}$ In this article we focus on their arguments against global egalitarianism. That is, we discuss the arguments of those who might be referred to as 'the egalitarian critics of global egalitarianism'.

Our discussion is structured as follows. After offering a more detailed description of global egalitarianism and its egalitarian critics (section I), we consider seven types of criticisms, each pointing to a specific disanalogy between domestic and international arenas which allegedly justifies the restriction of principles of egalitarian justice to the former. Such disanalogies invoke, respectively, social cooperation (section II), state coercion (section III), appropriate agency (section IV), national responsibility (section V), shared social meanings (section VI), international pluralism (section VII) and feasibility (section VIII).

${ }^{3}$ See, for example, Iris Marion Young, 'Responsibility and Global Labour Justice', Journal of Political Philosophy, 12 (2004), pp. 365-88, and Christian Barry and Sanjay Reddy, International Trade and Labor Standards: A Proposal for Linkage (New York: Columbia University Press, 2008). See also Thomas Nagel's remarks in his 'The Problem of Global Justice', Philosophy and Public Affairs, 33 (2005), pp. 113-47, p. 141.

${ }^{4}$ Prominent advocates of realism are E.H. Carr, The Twenty Years' Crisis 1919-1939: An Introduction to the Study of International Relations (London: Palgrave, 2001), Hans J. Morgenthau, Politics Among Nations: The Struggle for Power and Peace (New York: McGraw-Hill, 1993), and Kenneth Waltz, Theory of International Politics (Boston, Mass: McGraw-Hill, 1979).

${ }^{5}$ See, for example, Robert Nozick, Anarchy, State, and Utopia (Oxford: Blackwell, 1974) and Friedrich A. von Hayek, The Constitution of Liberty (London: Routledge, 1990).

${ }^{6}$ See Michael Walzer, Thick and Thin: Moral Argument at Home and Abroad (Notre Dame, Indiana: University of Notre Dame Press, 1994).

${ }^{7}$ See, for example, Harry Frankfurt, 'Equality as a Moral Ideal' in his The Importance of What We Care About (Cambridge: Cambridge University Press, 1988), Joseph Raz, The Morality of Freedom (Oxford: Clarendon Press, 1986), pp. 217-44, and Derek Parfit, 'Equality and Priority', Ratio, 10 (2007), pp. 202-21. For an illuminating discussion of these issues see Larry Temkin, Inequality (New York: Oxford University Press, 1993).

${ }^{8}$ Most notably, John Rawls, The Law of Peoples (Cambridge, MA: Harvard University Press, 1999), and David Miller, On Nationality (Oxford: Clarendon Press, 1995) and National Responsibility and Global Justice (Oxford: Oxford University Press, 2007). 
We argue that none of these criticisms - both individually and jointly - is sufficient to refute global egalitarianism. Our arguments in this essay are thus entirely negative: we do not present a comprehensive case in favour of global egalitarianism, but simply discuss a class of challenges advanced against this view, and conclude that they do not provide any conclusive reason to reject it. Even if our arguments are negative, our aim in this article is also constructive: by examining closely these critiques we hope to point towards ways in which egalitarian doctrines must be further developed, strengthened, and refined if they are to offer a convincing response to questions of international ethics and global justice. Whether they can successfully do so remains an open question.

\section{Global egalitarianism and its egalitarian critics}

Global egalitarianism indicates a family of views holding that, at a fundamental level, justice places limits on permissible global inequalities. ${ }^{9}$ Of course, one can advocate policies and institutional arrangements that would mitigate inequalities worldwide without being a global egalitarian. Reforms with inequality-reducing effects may be adopted, for instance, in pursuit of the humanitarian goal of meeting people's basic needs so as to improve the absolute position of the globally disadvantaged. ${ }^{10}$ Global egalitarians can recognise the merits of this and other reasons for supporting inequality-reducing policies, but they claim further that at least some international inequalities stand in need of special justification qua inequalities.

A broad range of conceptions of justice may fall within the category of global egalitarianism as we have defined it. Here, we will not attempt to discuss any particular one of them, but will only illustrate the various parameters along which they may differ from one another. In particular, global egalitarian conceptions can be distinguished in terms of which subjects, goods, and distributive standards they deem to be of ethical relevance in assessing distributive shares.

The subjects of a conception of global egalitarian justice indicate among whom equality is to be sought. Global egalitarian conceptions may, for example, take nation-states as their subjects, maintaining that there are limits to how steep inequalities in wealth, political influence, or other natural and social resources

\footnotetext{
${ }^{9}$ In order to be maximally comprehensive, we do not commit ourselves to any specific account of justice. For the purposes of this article, principles of justice are understood as a class of principles grounding particularly stringent distributive duties. Global egalitarians take different views on the justification of such principles. Some, for instance, see them as dependent on the existence of certain kinds of social institutions or relations (for example, Thomas Pogge, Charles Beitz - in his early work - and Darrel Moellendorf) while others reject this institutionalist view (for example, Simon Caney and Kok-Chor Tan). Our account aims to be neutral across these different positions.

${ }^{10}$ This point is made by David Miller in 'Against Global Egalitarianism', The Journal of Ethics, 9 (2005), pp. 55-79, esp. pp. 58-9. Notice that Miller's definition of global egalitarianism is narrower than ours. In particular, unlike Miller, we do not claim that (i) global egalitarians always condemn global inequalities as intrinsically wrong - as opposed to wrong because they undermine some other, more foundational, value - and (ii) the only inequalities that matter to them are inequalities between persons - rather than between states or groups. We shortly elaborate on these points in the main text.
} 
should be between them. ${ }^{11}$ Alternatively, they may focus on inequalities in the distribution of valued resources amongst persons. ${ }^{12}$

The goods of a conception of global egalitarian justice constitute, as Sen has put it, the 'evaluative space' of that conception. ${ }^{13}$ Examples of such goods include: capabilities, opportunities, income and wealth, economic power, and civil and political rights. ${ }^{14}$

Finally, global egalitarian conceptions may differ in the distributive standards they employ. A global eqalitarian conception might defend flat equality as its preferred distributive criterion, but need not do so. Global egalitarians are not committed to always viewing all inequalities in the relevant domain as evil and regrettable. What inequalities stand in need of redress, and to what extent, depends on the particular justification invoked in support of global egalitarian standards. For instance, some such justifications might appeal to considerations of responsibility, holding that only inequalities due to circumstances, not to subjects' responsible choices, should be rectified. ${ }^{15}$ Or else, global egalitarians might endorse Rawls's argument from the original position and conclude that any institutional arrangements engendering departures from equality require justification to those who fare worst under them. ${ }^{16}$ In sum, what distinguishes global egalitarian doctrines is the claim that justice places limits on permissible global inequalities along the relevant dimensions between the relevant subjects.

The egalitarian critics of global egalitarianism oppose this view. They affirm that inequalities are a reason for concern domestically, but not globally. Since they affirm egalitarian principles in the domestic sphere, such critics bear the argumentative burden of showing that the considerations grounding egalitarian justice within political communities do not also ground it globally. To do so, they need to produce persuasive arguments for two conclusions: one is moral, the other

${ }^{11}$ Brian Barry once held a position of this kind. See his 'Do Countries Have Moral Obligations? The Case of World Poverty', in Sterling M. McMurrin (ed.), The Tanner Lectures on Human Values Volume II (Salt Lake City: University of Utah Press, 1981). David Miller also gestures towards this position when discussing power inequalities between societies in National Responsibility and Global Justice, pp. 75-6.

12 So-called 'cosmopolitan' theorists typically hold this view. Prominent contemporary defences of cosmopolitanism are offered by Charles R. Beitz in Political Theory and International Relations with a new afterword (Princeton, NJ: Princeton University Press, 1999) and Thomas W. Pogge, Realizing Rawls (Ithaca: Cornell University Press, 1989). More recent statements of cosmopolitanism are offered by Moellendorf, Cosmopolitan Justice, Caney, Justice beyond Borders, and Tan, Justice without Borders.

13 Amartya K. Sen, Inequality Reexamined (Cambridge, MA: Harvard University Press, 1992), p. 73.

${ }^{14}$ Leading discussions of such goods include John Rawls, A Theory of Justice (Cambridge: Harvard University Press, 1971), John Rawls, 'Social Unity and Primary Goods,' in Amartya Sen and Bernard Williams (eds), Utilitarianism and Beyond (Cambridge: Cambridge University Press, 1982), pp. 159-86, Amartya Sen, Commodities and Capabilities (Amsterdam: North-Holland, 1985), and the essays in Amartya Sen and Martha Nussbaum (eds), The Quality of Life (New York: Oxford University Press, 1993). For discussions of the relevant goods in the global context, see also Simon Caney, 'Cosmopolitan Justice and Equalizing Opportunities', Metaphilosophy, 32 (2001), pp. 113-34, and Thomas Pogge, 'Human Flourishing and Universal Justice', Social Philosophy and Policy, 16 (1999), pp. 333-61 (reprinted as chapter 1 of his World Poverty and Human Rights).

${ }^{15}$ We shall discuss the relevance of considerations of (national) responsibility to global equality in section $\mathrm{V}$ of this article. Cf. the position on domestic justice known as luck-egalitarianism discussed in Elizabeth Anderson, 'What is the Point of Equality?', Ethics, 109 (1999), pp. 287-337.

${ }^{16}$ Rawls, A Theory of Justice. It is because Rawls treats equality as a morally privileged benchmark that he counts as an egalitarian in our sense. Strict prioritarians - who enjoin us simply to maximise the worst representative socioeconomic position - would not be egalitarians in our sense, since they do not maintain that there are restrictions on permissible inequalities. 
empirical. ${ }^{17}$ On the one hand, they must provide a plausible account of the 'normative factors' ${ }^{18}$ which are relevant to justifying egalitarian concern. On the other, they must show that these normative factors are either not present at all, or at least not present in the requisite degree and form on the global plane to justify global egalitarianism. In what follows, we examine seven anti-global-egalitarian arguments to this effect.

\section{Social cooperation}

One important challenge to global egalitarianism focuses on a purported disanalogy between the relations of social cooperation obtaining between fellow citizens, and those obtaining between persons who do not share a state. Those who reject global egalitarianism on this ground must defend the moral claim that social cooperation is indeed a necessary condition for egalitarian duties to apply; and they must make a plausible empirical case that cooperation of this kind does not exist at the global level.

What then is social cooperation, and why might it be thought that principles of egalitarian justice apply only when it is present? The idea of social cooperation can be understood in a variety of ways and the plausibility of these anti-globalegalitarian arguments depends a great deal on which understanding is employed. In particular, we consider three such understandings: social cooperation as (i) fair reciprocity, (ii) interaction against stable common rules, (iii) reciprocity in the production of social goods. We show that the anti-global-egalitarian argument from social cooperation is either morally implausible or, if it is morally plausible, its egalitarian implications cannot be confined to the domestic arena.

\section{(i) Fair reciprocity}

Some theorists have conceived of the relevant notion of social cooperation in strongly moralised terms, linking it with Rawls's conception of a society. On this view, social cooperation exists only when a group of people interact guided by the idea of reciprocity and fair terms of cooperation. ${ }^{19}$ A society is, according to Rawls, 'a more or less self-sufficient association of persons who in their relations to one another recognise certain rules of conduct as binding and who for the most part act in accordance with them [...] '. ${ }^{20}$ It is 'a system of cooperation designed to advance the good of those taking part in it'. ${ }^{21}$

\footnotetext{
${ }^{17}$ As also pointed out by Andrea Sangiovanni in his 'Global Justice, Reciprocity, and the State', Philosophy and Public Affairs, 35 (2007), pp. 3-39, p. 8.

${ }^{18} \mathrm{We}$ borrow this phrase from Shelly Kagan. See his 'The Structure of Normative Ethics', Philosophical Perspectives, 6 (1992), pp. 223-42.

${ }^{19}$ See, for example, Samuel Freeman, 'The Law of Peoples, Social Cooperation, Human Rights, and Distributive Justice', Social Philosophy and Policy, 23 (2006), pp. 29-68, p. 37.

${ }^{20}$ Rawls, A Theory of Justice, p. 4.

${ }^{21}$ Ibid., p. 4.
} 
One can see why those with egalitarian sympathies might maintain that the existence of social cooperation so understood is sufficient for the applicability of egalitarian concern. But the idea that it could also be necessary for the application of principles of egalitarian justice seems rather implausible. To see this, consider the kinds of contexts in which social cooperation of this type would be absent and thus where it would maintain that egalitarian demands would be out of place.

According to this form of cooperation-based egalitarianism, egalitarian demands would not be applicable within any social systems whose rules were not recognised as binding by all participants, or which were not designed for mutual advantage. A social system whose rules were designed by small elites for their own benefit and simply imposed upon others would be of this kind, when it is precisely these types of social systems that give rise to the most morally objectionable inequalities. Viewing social cooperation (understood in this way) as a necessary condition for the applicability of egalitarian demands would have unduly conservative implications, and would restrict implausibly the scope of egalitarian concern. ${ }^{22}$ If their argument is to be tenable, critics of global egalitarianism cannot appeal to social cooperation so understood.

\section{(ii) Interaction against the background of a relatively stable set of common rules}

Many who are sympathetic to Rawls's overall account of justice have (for the reasons discussed above) understood the idea of social cooperation more broadly. Thomas Pogge, for example, has argued that social cooperation of the relevant kind exists in any 'comprehensive and reasonably self-contained system of social interaction'. ${ }^{23}$ While this understanding of social cooperation is significantly broader than the moralised notion employed by Rawls, it is still much narrower than social interaction.

Not all forms of social interaction rise to the level of social cooperation. Social interaction can take place between agents who do not coexist in a comprehensive and reasonably self-contained system. For example, two agents who occasionally trade with one another, but do not interact against a background of common and reasonably stable terms, are not engaging in social cooperation so understood. Social cooperation exists when the rules and practices that govern interaction are generally known, and sufficiently complied with to enable reasonably settled expectations about agents' behaviour.

It is clear enough that nearly any modern society is a scheme of social cooperation so understood. The terms of such social cooperation consist in laws and other social rules that govern matters such as what kinds of things can be owned (and by whom), how they can be acquired, transferred, relinquished, and

22 Arash Abizadeh has forcefully argued for this conclusion in 'Cooperation, Pervasive Impact, and Coercion: On the Scope (not Site) of Distributive Justice', Philosophy \& Public Affairs, 35 (2007), pp. 318-58, at pp. 330-1. In particular, Abizadeh helpfully distinguishes between three different understandings of what a Rawlsian basic structure is - in terms of social cooperation, pervasive impact and coercion - and argues that, on none of these interpretations, the scope of egalitarian demands can plausibly be restricted to the domestic arena. On similar issues see also Simon Caney, 'Global Distributive Justice and the State', Political Studies, 57 (2008), pp. 487-518.

${ }^{23}$ Pogge, Realizing Rawls, p. 21. 
forfeited, how markets and the production system are structured, the manner in which political decisions are made, what persons are permitted to and forbidden from doing with their own and one another's bodies, and so on. Notice however that, even a social order that lacks a 'state' could count as a scheme of social cooperation thus understood so long as the norms governing the conduct of the agents within it are generally recognised and honoured to a sufficient extent. ${ }^{24}$

It seems fairly obvious that social cooperation of this kind does exist on the global plane. The arrangements constituting the 'terms' of social cooperation include global markets in capital and labour, rules governing global trade and monetary arrangements, and indeed constitutive features of the modern state such as its sovereign rights to tax, to bind citizens through agreements, to fix membership, to control the use of natural resources within its territorial domain, to represent its interests in international bargaining and rule setting and so on. ${ }^{25}$ Those who conceive of social cooperation in this broader sense and who see the existence of such cooperation as a necessary condition for the applicability of egalitarian demands, cannot easily deny that this condition is met at the global level.

\section{(iii) Reciprocity in the production of social (public) goods}

The discussion in the previous section does not engage with the arguments advanced by a third class of cooperation-based critics of global egalitarianism. These critics do not deny that social cooperation exists on a global plane. Indeed, they sometimes even affirm that there is a great deal of such cooperation. They argue, however, that egalitarian demands apply only within schemes of social cooperation that have particular characteristics which, while present within states, are lacking at the global level. Brian Barry and, more recently, Andrea Sangiovanni, for example, have argued that egalitarian justice is presently applicable only within states because the citizens of those states stand in specific kinds of strong reciprocal relations with one another in virtue of their joint engagement in the production of primary social goods. ${ }^{26}$ In Sangiovanni's words 'we owe obligations of egalitarian reciprocity to fellow citizens and residents in the state, who provide us with the basic conditions and guarantees necessary to develop and act on a plan of life, but not to noncitizens, who do not'.27

Clearly, much depends on exactly what it means for one agent to provide another agent with such basic conditions and guarantees. As reciprocity-based egalitarians recognise, it is not usually the case that fellow citizens and residents in a state directly provide each other with such conditions and guarantees. Rather, citizens and residents provide support for each other indirectly, by upholding the

\footnotetext{
${ }^{24}$ For discussion see Pogge, Realizing Rawls, esp. pp. 23-5.

${ }^{25}$ For a general discussion of the multiple dimensions of global 'social cooperation' so understood see John Baylis and Steve Smith (eds), The Globalization of World Politics: An Introduction to International Relations (Oxford: Oxford University Press, 2005).

${ }^{26}$ Brian Barry, 'Humanity and Justice in Global Perspective', in B. Barry, Liberty and Justice: Essays in Political Theory, 2 (Oxford: Clarendon Press, 1991), pp. 182-210, esp. 194 and Sangiovanni, 'Global Justice'.

${ }^{27}$ Sangiovanni, 'Global Justice', p. 19.
} 
institutional arrangements that govern their mutual relations qua members of society. ${ }^{28}$ The question, then, is what kind of support individuals must provide for them to be justified in making egalitarian demands upon one another?

One might insist, for example, that egalitarian duties are owed to those who provide financial and other active forms of support for these agencies and institutional arrangements. Yet while reciprocity-based egalitarians certainly think that the idea of reciprocity includes this type of support, they do not hold that it is strictly necessary for one to count as deserving of egalitarian concern. And it is obvious enough why, since it would otherwise follow from this position that those who are exempted from paying taxes or do not provide such support within domestic societies would fall outside the scope of egalitarian justice.

Instead, the idea of 'providing support' is understood more broadly, including 'simple compliance' with 'the full range of our everyday legally regulated activity'. ${ }^{29}$ The type of contribution which everyone must make to fall within the scope of egalitarian concern is therefore clearly quite minimal, and in fact potentially objectionable in virtue of such minimalism. Even critics with egalitarian sympathies may object that, following this criterion, we would be required to redistribute resources from the capable and hard-working to those who 'uphold' state institutions simply by submitting to them and refraining from undermining them. ${ }^{30}$ Such critics will not deny that others are 'owed a fair return for what they had given you', but they will deny that such a fair return translates into egalitarian duties. $^{31}$

Even if reciprocity-based egalitarians had a convincing reply to this objection, ${ }^{32}$ they would still need to show that, unlike citizens and residents, foreigners have not submitted themselves to a system of laws and social rules that are necessary to sustain our lives as producers and biological beings. ${ }^{33}$ This would be very difficult for them to show. Foreigners submit themselves to various international norms which in turn considerably influence our access to resources that are central to the lives that we lead. These include countries' right to extract resources at whatever prices they deem fit, regardless of what costs this imposes on their citizens, and their right to control borders. ${ }^{34}$ Wealthy states routinely exclude outsiders who would wish to seek opportunities within their borders, thereby protecting and enhancing the value of insiders' opportunities. ${ }^{35}$ Such exclusion also lowers the

${ }^{28}$ Cf. Onora O'Neill's distinction between primary and secondary agents of justice in her 'Agents of Justice', Metaphilosophy, 32 (2001), pp. 180-95.

${ }^{29}$ Sangiovanni, 'Global Justice', p. 20.

${ }^{30}$ See, famously, Nozick, Anarchy, State and Utopia.

31 Of course, what reciprocity requires depends a great deal on the particular relationship in question. For a helpful discussion, see Richard J. Arneson, 'Do Patriotic Ties Limit Global Justice Duties?', The Journal of Ethics, 9 (2005), pp. 127-50, esp. pp. 135-6.

32 Sangiovanni offers a good one, arguing that even though some may contribute more to the overall joint social product then others, their having made such contributions depends on background institutions to which all contributed, even if only through their submission. Sangiovanni, 'Global Justice', p. 26.

33 Arash Abizadeh also considers this version of the argument from social cooperation and forcefully challenges the idea that the provision of primary goods could be an 'existence condition' of justice. Abizadeh, 'Cooperation, Pervasive Impact, and Coercion', pp. 336-7.

${ }^{34}$ For an interesting discussion, see Leif Wenar, 'International Property Rights and the Resource Curse', Philosophy and Public Affairs, 36 (2008), pp. 2-32.

${ }^{35} \mathrm{See}$, for example, the discussion in Eric Cavallero, 'An Immigration-pressure Model of Global Distributive Justice', Politics, Philosophy \& Economics, 5 (2006), pp. 97-127. 
prices at which goods can be produced abroad for consumption by the world's privileged. Were outsiders free to move across borders, the cost of labour in poor countries would be significantly higher since there would be many fewer people competing for such employment opportunities as currently exist in production for export. $^{36}$

Consider further the rules which confer rights to trade on countries. At present, any country, regardless of how rich it is and regardless of how much its trade policies might affect others, is legally free to choose autarky - to close itself off from the rest of the world. Moreover, in case it has not chosen to commit itself to the WTO or some other agreement, it can discriminate between its trading partners on whatever grounds it wishes, which in turn dramatically affects the opportunities of people throughout the world. In light of this, there seems to be no grounds on which it can be plausibly claimed that outsiders do not 'participate' in the relevant sense to the production of social goods crucial to the design and realisation of our plans of life. From this it follows that they should fall within the scope of egalitarian concern also on this third interpretation of social cooperation.

\section{State coercion}

Some theorists have argued that egalitarian justice exclusively applies to domestic political communities in virtue of the particular form of coercion exercised within them. ${ }^{37}$ This, which we shall from now on call 'the coercion view', consists of a moral and an empirical claim. The moral claim is that egalitarian justice only applies in the presence of a particular form of coercion. The empirical claim is that the factor (coercion of a particular kind) which triggers egalitarian demands at the domestic level is absent at the international one. We consider each of these claims in turn.

\section{(i) Coercion and egalitarian justice}

To begin with, we need to ask why coercion is thought to stand in need of special justification. One promising line of defence for the coercion view appeals to the importance of respecting persons' capacity to set and pursue ends for themselves - of respecting their autonomy. ${ }^{38}$ On this view, coercion stands in need of special justification because it can undermine autonomy. When I am coerced, I do not act out of my own will but I am instead subject to the will of another. ${ }^{39}$

${ }^{36}$ See, for example, Nigel Harris, 'Migration without Borders: The Economic Perspective' (2004), draft, Migration without borders series. Available at http://unesdoc.unesco.org/images/0013/001391/ 139151e.pdf

37 Michael Blake, 'Distributive Justice, State Coercion, and Autonomy', Philosophy and Public Affairs, 30 (2001), pp. 257-96, Nagel, 'The Problem of Global Justice'. Some of these points were originally made by Richard W. Miller in 'Cosmopolitan Respect and Patriotic Concern', Philosophy and Public Affairs, 27 (1998), pp. 202-24.

38 Our account of the coercion view follows principally Michael Blake's in 'Distributive Justice'.

39 See Blake, 'Distributive Justice', p. 272. On the specific effects of coercion on persons' will see Onora O’Neill, Bounds of Justice (Cambridge: Cambridge University Press, 2000), ch. 5. 
Coercion, however, need not always be morally objectionable. Indeed, coercion seems often justified precisely because it protects, rather than undermines, persons' autonomy: for instance, when it is employed to uphold contracts, compel employers to respect basic labour standards, provide educational opportunities, secure rights to participate in political activity, and deter criminal conduct. ${ }^{40}$ Such protections are arguably among the necessary preconditions for developing and exercising a capacity for autonomy. The autonomy of those constrained by such rules may be undermined, but this can be justified on autonomy-based grounds because their coercive imposition is required to protect their own autonomy as well as that of a great many others.

Since any coercively upheld system of laws will constrain the autonomy of some and promote the autonomy of others, the question is: How should such laws be designed so as to manifest adequate respect for the autonomy of all? Proponents of the coercion view have answered by suggesting that coercively upheld social rules should be designed to ensure distributive equality. When coercively imposed rules generate an egalitarian distribution, all citizens have (roughly) the same opportunities to act in pursuit of their ends and nobody's autonomy is being unduly undermined. Since no one can constrain others' actions any more than others can constrain hers, everyone has reason to consent to the coercive rules in question. In such circumstances, state coercion is thus justified in the eyes of all.

This is the justificatory rationale at the heart of the coercion view. One can of course question such a rationale and the link it establishes between coercion, autonomy and egalitarian justice. Libertarians, for example, have argued that a commitment to autonomy supports nothing more than a minimal state. ${ }^{41}$ Indeed, one could push this argument even further and defend anarchy on the grounds that no form of coercion is compatible with autonomy. ${ }^{42}$ Since engaging with these objections would take us too far from the topic of the present discussion, we will grant, for the sake of argument, the central justificatory rationale of the coercion view and turn to the empirical claim that coercion of the requisite kind is absent at the global level. If this claim proves untenable, the coercion view will not have anti-global egalitarian implications.

\section{(ii) Coercion on the global plane}

Coercion abounds at the global level and advocates of the coercion view do not deny it. ${ }^{43}$ However, they insist that it is not of the right kind to trigger egalitarian distributive principles. Why is this so? Three reasons are typically invoked by them.

The first asserts that while domestic coercion is systemic and ongoing, international coercion is mostly a matter of one-off interactions - for example,

${ }^{40}$ For this reason some have contested the assumption that coercion is indeed prima facie morally problematic, see Arneson, 'Do Patriotic Ties Limit Global Justice Duties?', pp. 136-42, and Ryan Pevnick, 'Political Coercion and the Scope of Distributive Justice', Political Studies, 56 (2008), pp. 399-413.

${ }^{41}$ See, for example, Nozick, Anarchy, State and Utopia.

42 Robert P. Wolff, In Defense of Anarchism (New York: Harper and Row, 1970).

43 Blake, 'Distributive Justice', p. 265. 
military intervention, economic sanctions, or blatant forms of arm twisting in international negotiations. Domestic coercion materialises in the form of coercively upheld rules having deep distributive effects over a bounded group of people. Accordingly, it is to those people and those people only that such distributive effects need to be justified. Since, it is alleged, no rules of this sort exist at the international level, justification through egalitarian distributive principles is simply out of place.

This empirical claim is implausible. It is perhaps true that some of the most obvious forms of international coercion consist in one-off interactions. But it is certainly true that there also exist international rules which substantially affect individuals' distributive shares world-wide. Some such rules are so deeply entrenched in our understanding of the international arena that we often fail to perceive their existence. Consider, once again, the sovereign state system itself, with all the powers and prerogatives it confers upon states, some of which, such as borders control, clearly involve forms of coercion against individuals with significant distributive effects across human beings. ${ }^{44}$ What is more, compliance with such rules is involuntary. Consider again institutions such as global markets in capital and labour, the rules governing global trade and monetary arrangements, and the constitutive features of the modern state. Such institutions are also coercively enforced (partly through the threat of sanctions), and undoubtedly have significant distributive effects. Of course, from a purely formal viewpoint, such institutions are, unlike the state system, voluntarily joined, but given the potentially unbearable costs of exclusion, participation can be described as coercive. ${ }^{45}$

Further, the mere fact that states have voluntarily chosen to be governed by such rules does not show that they are not coercively imposed on their people. Many governments are not minimally representative of the people they rule, and many more are merely minimally representative, privileging the protection of the interests of most advantaged citizens and non-citizens who can be expected to confer benefits upon them.

Proponents of the coercion view might reply by acknowledging the existence of coercion of the kinds described above, but nonetheless insist that they do not count as instances of egalitarian-justice-triggering coercion for either of the following two reasons.

First, they might argue, as Thomas Nagel seems to have recently suggested, that for there to be coercion of the right kind, those who exercise it must consider themselves under an obligation to justify their actions to their coercees. Since state representatives and officials take themselves to be under such an obligation towards their citizens, but not towards foreigners, egalitarian justice remains confined within domestic communities. ${ }^{46}$ This view is untenable. Requiring coercion to be justified only to those to whom we already think we owe a justification has unduly

\footnotetext{
${ }^{44}$ See Abizadeh, 'Cooperation, Pervasive Impact, and Coercion', pp. 348-50 for discussion.

${ }^{45}$ For valuable discussions of these points see David Grewal, Globalization and Network Power (New Haven and London: Yale University Press, 2008), and Mathias Risse, 'What to Say About the State', Social Theory and Practice, 32 (2006), pp. 671-98, esp. p. 681. Thomas Pogge has argued that the global economic order is coercively imposed by the world's wealthy and privileged on the world's poor in his World Poverty and Human Rights, esp. ch. 4.

46 Nagel, 'The Problem of Global Justice', pp. 128-30.
} 
conservative implications and places some of the most morally questionable forms of coercion beyond scrutiny. ${ }^{47}$

Second, advocates of the coercion view might contend that, though people's subjection to international rules is non-voluntary, such rules are not coercive in the requisite way because they are not enforced by a centralised agent such as a state government. This is what makes state coercion special. Absent a coercer enforcing norms by threatening sanctions, egalitarian justice does not apply. ${ }^{48}$

In response to this argument it seems quite natural to ask why, if coercion matters because of its effects on autonomy, just this highly specific form of centralised coercion should make such a moral difference? If coercion is a condition of egalitarian justice because of its effects on autonomy, then there seems to be no plausible reason to claim that autonomy-affecting international rules coercively upheld by a plurality of agents do not require special justification in just the same way as autonomy-affecting rules internally enforced by the state do. ${ }^{49}$ Suppose, however, that it could be shown that international rules are not coercively upheld and enforced but are merely non-voluntary. ${ }^{50}$ Given that such rules are undeniably autonomy-affecting, it would nevertheless be hard to see why, given the presuppositions of this view, the absence of coercion should make such a decisive moral difference.

\section{Agency}

Some have recently based their rejection of global egalitarian justice on considerations of agency. These writers argue that global egalitarian principles are implausible because there is no agent, or set of agents, who can be reasonably expected to act on them effectively. If there are no agents whose conduct a principle might plausibly guide, so the argument goes, then it is not really a principle at all. ${ }^{51}$ On this view, global egalitarian principles are not merely implausible; they are not principles at all since there are no agents who can apply them. $^{52}$

We can refer to this as the agency-based critique of global egalitarianism. To evaluate it, we need to ask whether the requirements it places on principles of justice are plausible and, if so, whether global egalitarian principles would necessarily fail to meet them. We shall argue that only some such requirements are plausible and that those plausible requirements are met on the global plane.

${ }^{47}$ For this line of critique against Nagel see Abizadeh 'Cooperation, Pervasive Impact and Coercion', pp. 348-50, A. J. Julius, 'Nagel's Atlas', Philosophy and Public Affairs, 34 (2006), 176-92, pp. 179-80, and Pevnick, 'Political Coercion and the Scope of Distributive Justice', pp. 403-6.

${ }^{48}$ Related to this is Risse's claim that what makes state coercion special is its distinctive immediacy and directness. See Risse, 'What to Say About the State', pp. $685 \mathrm{ff}$.

${ }^{49}$ On this point see Risse, 'What to Say About the State', p. 680.

${ }^{50}$ Cf. Sangiovanni, 'Global Justice', pp. 8-13.

51 This claim is explicitly made by Saladin Meckled-Garcia, 'On the Very Idea of Cosmopolitan Justice: Constructivism and International Agency', Journal of Political Philosophy, (2008), pp. 245-71.

52 So, for instance, Samuel Freeman argues that a 'global difference principle would be without both agency and object - no legal person to implement it, and no legal system to which it is applicable'. See Freeman, 'The Law of Peoples', p. 61. 
Let us begin by noticing that agency requirements may be of two types, depending on how they answer the following two questions:

(1) Must agents be causally capable of acting on the requisite normative principles, or must they additionally have the moral capacity to act on them?

(2) In applying such principles, must agents' conduct involve acting on specific perfect obligations, or may they act in a broad range of ways to further the principles' demands?

In what follows, we evaluate different versions of the agency-based critique, each offering a distinct answer to the above stated questions.

\section{(i) Causal vs. moral capacity}

Regarding the first question, it seems plausible to claim that, for a normative principle to apply to some domain, there must be agents to whom it is directed who are capable (either alone or jointly with others) ${ }^{53}$ of furthering its demands. Do global egalitarian principles satisfy this requirement? Our answer depends on our estimations of the capabilities of existing agents to further global egalitarian aims, but it seems implausible to suggest that there is nothing that existing agents could do in this regard. To affirm otherwise would require showing that no proposed institutional reforms on the global plane, such as alterations of the rules governing the flow of goods and people, and the extraction and sale of natural resources, could be expected to promote such goals.

Critics might produce, and in fact have produced examples of proposed reforms that, on reflection, would not obviously be of value in promoting global egalitarian justice. ${ }^{54}$ For instance, Samuel Freeman raises some worries about the ability of countries, acting independently, to apply egalitarian principles of justice such as Rawls's difference principle. On Freeman's view, 'this would require that each nation calculate the effects of its many decisions upon the worst off members of the world. This is not feasible, nor would it have the desired (or even desirable) effects'. 55

This may be true, but those who advocate a global difference principle would not need to require countries to act in this way, any more than supporters of a domestic difference principle would require of individual agents (including specific governmental agencies) that they act in this way. Instead, such countries could seek to co-ordinate with each other to reform the rules that govern their productive activities and interactions in such a way as to improve the position of the least advantaged representative group. Such efforts would require complex empirical investigations exploring practically feasible alternative institutional arrangements that would better promote egalitarian goals. Even though such investigations would be subject to uncertainty, there is no reason to assume, a priori, that they

\footnotetext{
53 The mere fact that no single agent can, acting alone, further the demands of a principle would not seem a good basis for dismissing the principle as impracticable.

${ }^{54} \mathrm{See}$, for example, Meckled-Garcia, 'On the Very Idea of Cosmopolitan Justice'.

55 See Freeman, 'The Law of Peoples', p. 62.
} 
would involve impossible informational demands or require unachievable forms of coordination.

To show that global egalitarian principles fail to satisfy the agency requirement (causally understood), one needs to prove a universal claim - that all agents out there fail to possess the requisite causal capabilities to promote global egalitarian aims. Even assuming the critics' worries to be correct, they only support an existential claim: that there are some means by which some agents cannot be expected to promote global egalitarian aims. Demonstrating this does not suffice to show that such aims cannot be promoted, any more than raising concerns about the effects of policies oriented towards promoting domestic equality would show that egalitarian principles are out of place within societies.

It might be argued that, although there are measures that agents could adopt to further global egalitarian goals, they would be unable to meet them completely, or even advance them very significantly. This too is an empirical claim, and it is not clear that it is true. However, even if it were true, it would be implausible to insist that it is a requirement of principles of morally just action that there be agents that are causally capable either of satisfying the principles' demands completely or furthering its demands very significantly in the here and now. ${ }^{56}$ Indeed, it is often the case that even the concerted efforts of a great many agents would not suffice to achieve fully the demands of principles of (domestic) justice, at least in the short and medium terms. ${ }^{57}$

To fully realise or significantly further a principle's demands, it may well be necessary not only for existing agents to seek to do so directly, but also for them to seek to bring into being other agents (regulatory agencies, judicial organs, etc.) that can do so. This is often the case in weak or failed states, in which, as a result of war, corruption, or misrule, agents with the requisite causal capabilities to further significantly egalitarian goals are often lacking. ${ }^{58}$ Of course, one might suggest that egalitarian principles are simply infeasible not only in the here and now, but in relation to the human condition as such. This consideration falls outside the scope of the agency-argument, and will be treated separately, in the final section of this article.

That said, it may still be argued that those agents who have the requisite causal capacities to further global egalitarian demands lack the moral capacities, in the sense that they are unlikely to find these demands compelling and act on them. This may indeed be true. It is implausible, however, to require of a principle of just action that it be very likely that agents who are causally capable of acting effectively on it do so. We would be loath to claim that principles of racial equality did not apply to the US in the early nineteenth century simply because very few people (other than the African slaves themselves) could be expected to adopt and further its demands, at least in the short and medium terms. ${ }^{59}$ Establishing a strong link between motivation and the applicability of principles of justice risks limiting

${ }^{56}$ For a cogent statement of this point, see Beitz, Political Theory and International Relations, p. 156.

${ }^{57}$ In the US of 1800 , for example, it may have been that there were no agents who, acting together, could have realised principles of racial equality completely, at least in the short term.

${ }^{58} \mathrm{We}$ take it as obvious that the mere fact that a state is characterised by weak institutions or rapacious officials such that no agents are causally capable of promoting significantly egalitarian goals does not in itself show that egalitarian demands would not apply to such a society.

59 Joseph Carens also discusses the example of slavery to highlight the potentially conservative implications of 'realistic' (hence likely to be effective) political theorising in his 'Realistic and 
moral theorising, as Robert Goodin has nicely put it, to 'the role of philosophical anthropology - mapping without comment the social practices we find around ourselves'. ${ }^{60}$

Let us now turn to the second dimension of agency-requirements. What kind of guidance should principles of just action demand of the agents who are to apply them?

\section{(ii) Perfect vs. imperfect duties}

Saladin Meckled-Garcia, a recent proponent of the agency-based critique, claims that principles of justice must:

a) set out perfect duties regarding distribution, b) specify a clear agent who must perform the duties, c) specify the agent's sphere of action, and d) serve an appropriate value/s by guiding the right action of that agent. ${ }^{61}$

Following Kant, we can understand the distinction between perfect and imperfect duties as being characterised by the fact that, unlike the former, the latter leave open both how the duty can be discharged, and to whom the duty is owed. ${ }^{62}$ In her book Faces of Hunger, for instance, Onora O'Neill gives the example of our duty to help the needy as a paradigmatic case of an imperfect duty. ${ }^{63}$ You must do something for some needy person, but there is no particular needy person for whom you need to do anything. There is also no specific thing you need to do for anyone. Your duty could be discharged by many different kinds of activities (giving aid, volunteering, engaging in political campaigns, etc.), and focused on many different persons.

Many of the duties to address issues that are of concern to global egalitarians would be imperfect in nature, since at present they would seem to require that agents act to bring about institutional reforms, policy changes, and indeed the creation of new agents capable of promoting the values they affirm. But is it plausible that principles of just action be restricted to those areas in which specific moral demands can be clearly parcelled out to specific agents? It would seem not.

Consider, for example, practices that were widespread in the past such as rules that restricted suffrage to men or specific social groups within society. Such practices seem to be paradigmatically unjust, and it is widely affirmed that principles of just action ought to demand that persons living within societies in which they prevailed ought to have reformed them. Yet such demands cannot plausibly be understood in terms of perfect duties allocating specific responsibilities

Idealistic Approaches to the Ethics of Migration', International Migration Review, 30 (1996), pp. 156-70, esp. pp. 164-6.

${ }^{60}$ Robert E. Goodin, 'Political Ideals and Political Practice', British Journal of Political Science, 25 (1995), pp. 37-56, p. 40.

${ }^{61}$ Meckled-Garcia, 'On the Very Idea of Cosmopolitan Justice'.

${ }^{62}$ Here we follow the accounts developed in Onora O'Neill, Constructions of Reason: Explorations of Kant's Practical Philosophy (Cambridge: Cambridge University Press, 1990) and Thomas Hill, Dignity and Practical Reason in Kant's Moral Theory (Ithaca: Cornell University Press, 1992).

${ }^{63}$ Onora O’Neill, Faces of Hunger: An Essay on Poverty, Justice, and Development (London: Allen and Unwin, 1986). 
to specific individuals given that the institutional reforms necessary to eradicate such practices can only fall on the group of all persons as a whole. ${ }^{64}$

It might of course be argued that, although there were indeed justified moral demands that people living within such societies take action to change their societies' practices, such demands do not amount to principles of just action. However, this would seem to restrict artificially and unduly the scope of principles of just action. When institutional arrangements are unjust, and indeed especially when they are grievously unjust, the moral demands to reform them cannot typically be allocated as perfect duties to specific agents, and yet whatever principles are invoked as the basis of the demand that such agents realise such reforms seem, paradigmatically, to be principles of just action. ${ }^{65}$

\section{National responsibility}

Some critics have complained that, by requiring transfers (in whatever form) from one country to another, global egalitarian principles ignore the moral relevance of national responsibility in a plurality of objectionable ways. To illustrate their case, such critics present structurally similar examples. ${ }^{66}$ They ask us to imagine two reasonably well-governed and equally wealthy societies, call them $\mathrm{A}$ and $\mathrm{B}$, and to observe their 'progress' over time. One of them, A, takes policy decisions which lead to significant wealth-increases. Due to its different social ethos - for example, more rural than industrial - B adopts different policies and its economy therefore follows a different course. As a result, after a number of years, A is considerably more prosperous than $\mathrm{B}$, though both economies meet a relevant threshold of sufficiency.

Under these circumstances, the critics argue, global egalitarians would require further redistribution between the two countries, and this seems problematic on three counts: (i) it would place unfair burdens on the most productive political communities; (ii) it would undermine national self-determination, and (iii) it would disincentivise political communities from taking responsibility for their fate. ${ }^{67} \mathrm{We}$ shall examine each of these charges in turn.

Before doing so, let us signal the presence of two important (and related) inaccuracies in the model example just described. First, it is false that all global egalitarian doctrines would require the transfers imagined in the example. A global

${ }^{64}$ For discussion, see Amartya Sen, 'Consequential Evaluation and Practical Reason', Journal of Philosophy, 96 (2000), pp. 477-502, and Thomas Pogge, 'O’Neill on Rights and Duties', Grazer Philosophische Studien, 43 (1992), pp. 233-47.

${ }^{65}$ On the implausibility of confining justice to the realm of perfect duties see Allen Buchanan, 'Justice and Charity', Ethics, 97 (1987), pp. 558-75, esp. pp. 570-1. For further critical discussion of agency-based arguments against global egalitarianism see Laura Valentini, 'Global Justice: Cosmopolitanism, Social Liberalism, and the Coercion View' (University College London: Ph.D. Thesis, 2008), ch. 5.

${ }^{66}$ This type of argument has been advanced by John Rawls, The Law of Peoples, pp. 117-8, David Miller, 'Justice and Global Inequality', in Andrew Hurrel and Ngaire Woods (eds), Inequality, Globalization, and World Politics (Oxford: Oxford University Press, 1999), pp. 187-210, esp. pp. 193-5, and Michael Blake, 'Distributive Justice', pp. 289-94.

${ }^{67}$ As Miller puts it: 'Why be an ant, if the grasshoppers are guaranteed equal access to your store of winter provisions?' in National Responsibility and Global Justice, p. 71. Detailed discussion of all three claims may be found in chapter 3 of Miller's book. 
egalitarian need not affirm that transfers between societies ought to take place when inequalities result from the productive choices of some (presumably legitimate) regime. ${ }^{68}$ That is, global egalitarians can hold that, all things being equal, justice places limits on permissible inequalities among countries, but that all things are not equal when some countries have lesser shares of wealth because of decisions or actions for which they can reasonably be held responsible - which is precisely the case illustrated in our model example. ${ }^{69}$

Second, though supported by some sociological and economic studies, the thesis that a country's wealth is exclusively determined by endogenous factors - such as its institutional choices - is questionable. ${ }^{70}$ Scholars have often pointed to countries' natural resource-endowment, or position in the international economy, as crucial determinants of their prosperity. ${ }^{71}$ Indeed, in most cases, all factors resource-endowment, domestic and international institutions, history, the influence of powerful international actors - play some role in defining a country's wealth. Though it is hard, perhaps impossible, to establish whether, and to what extent, these different factors have contributed to a country's wealth, we can safely exclude that this only depends on the quality of its domestic institutions. ${ }^{72}$ This means that one of the central assumptions in our model example, which lends it much of its intuitive plausibility, is untenable. Political communities cannot be taken to be the exclusive makers of their own fate, for the opportunities they confront significantly depend on the wider social environment they inhabit. It is against the background of these considerations that the three claims central to the responsibility-based challenge to global egalitarianism should be evaluated.

\section{(i) Unfair burdens}

Let us assume that, all things considered, a global egalitarian doctrine - say a globalised version of Rawls's difference principle - would require the transfers imagined in our example. It is not obvious that the burdens imposed by such transfers would be any more objectionable than those imposed by the kinds of domestic institutions advocated by egalitarians, including Rawls. After all, domestic equality-sustaining policies might also involve transferring (through a coercively enforced tax system and other means) resources from the more industrious to the less industrious.

One problem with rejecting even mildly equality-promoting transfer schemes amongst households or countries is that it seems to penalise unduly many people for decisions and conduct in which they took no part. Even if one holds that

\footnotetext{
68 This is noted by Miller in National Responsibility and Global Justice, pp. 69-70.

${ }^{69}$ Such a global egalitarian view is explored by Alexander Cappelen in 'Responsibility and International Distributive Justice', in Andreas Føllesdal and Thomas Pogge (eds), Real World Justice (Berlin: Springer, 2005), pp. 209-22.

70 This point is forcefully made by Pogge, World Poverty and Human Rights, ch. 4, and acknowledged by Miller in National Responsibility and Global Justice, p. 69.

${ }^{71}$ See, for example, Mathias Risse's (anti-global-egalitarian) discussion of what he calls geographical, institutional, and integration factors in 'How Does the Global Order Harm the Poor', Philosophy and Public Affairs, 33 (2005), pp. 349-76. See also Miller's remarks in National Responsibility and Global Justice, ch. 9.

72 See Charles R. Beitz, 'Rawls's Law of Peoples', Ethics, 110 (2000), pp. 669-96, p. 690, for discussion.
} 
inequalities amongst persons resulting from their responsible choices are morally unproblematic, it is difficult, from an egalitarian point of view, to argue that inequalities arising from the choice of some set of people should simply be passed on to another set of people - for example, their children or future members of society.

We do not doubt the moral significance of the idea of national responsibility and indeed of one's generation 'inheriting' responsibilities from its predecessors. ${ }^{73}$ However, this idea does not require or provide support for the view that the members of one society ought to be made to bear the entire economic costs of the decisions made by themselves or by earlier members, or that familial responsibility entails that nothing should be done to mitigate inequalities amongst children that result from parental decisions.

Rawls, along with most domestic egalitarians, does not consider such inequality-limiting transfers amongst households to be unduly burdensome in the domestic case. Indeed, as discussed by Thomas Pogge, his difference principle would support institutional arrangements that allow children to bear the economic costs of their parents' decisions only insofar as doing so is necessary to provide incentives for decision-making that will tend to raise the worst representative socioeconomic position. Why would this line of reasoning be invalid on the global plane $?^{74}$

To justify the disanalogy, critics might want to appeal to the particular co-operative or coercive relations holding between citizens within society or to the lack of appropriate agency. As we have seen, however, cooperation, coercion, and agency-based arguments against global egalitarianism do not succeed.

\section{(ii) Self-determination}

It is not clear how an egalitarian could object to the transfers imagined in the example by appeal to the value of self-determination. After all, nearly every domestic tax system involves the transfer of resources from some households which are wealthier due (at least in part) to their greater industriousness to other households which are significantly less well off due (at least in part) to their lack of industriousness. Of course, not all egalitarians would endorse transfers of this kind even in the domestic case. They may hold that insofar as the different shares of $\mathrm{A}$ and $\mathrm{B}$ are due to choice and effort rather than circumstances, no equalitypromoting redistribution is justified. But, as mentioned above, global egalitarians can also endorse such a view. They may insist that transfers be undertaken only to address inequalities resulting from circumstances for which the agents in question cannot plausibly be held responsible.

${ }^{73}$ For a very interesting discussion, see David Miller, 'Holding Nations Responsible', Ethics, 114 (2003-2004), pp. 240-68, and National Responsibility and Global Justice, ch. 6.

74 See Thomas W. Pogge, 'Rawls on International Justice', Philosophical Quarterly, 51 (2001), pp. 246-53, esp. pp. 249-50, and 'Do Rawls's two Theories of Justice Fit Together?', in Rex Martin and David Reidy (eds), Rawls's Law of Peoples: A Realistic Utopia? (Malden, MA: Blackwell, 2006), pp. 206-25. 
Further, global egalitarians can support such transfers on the same grounds that comparable transfers are advocated in the domestic context - as a necessary means to preserving a fair framework in which individuals and communities can truly be said to be self-determining. Rawls's difference principle, for instance, is part of a scheme of social justice which is ultimately meant to mitigate the effects of morally arbitrary factors on people's life-prospects so that they can be meaningfully regarded as autonomous, as authors of their own lives. ${ }^{75}$ For this to be the case, the background against which individuals develop their life plans and take responsibility for the consequences of their choices must be a fair one.

The maintenance of such a fair background requires considerable institutional regulation. This is because, as Rawls points out, the fairness of society as a whole does not supervene on the fairness of individual transactions: the cumulative effects of individually fair transactions might still generate unfairness at the macro-level. As he explains, 'the overall result of separate and independent transactions is away from and not toward background justice' ${ }^{76}$ Absent a system of rules ensuring background justice, the distribution of resources between people might end up creating such wide inequalities and power differentials as to undermine significantly the capacity of many to make genuine choices and thus be meaningfully selfdetermining. 77

Critics might accept this conclusion, but still insist that if societies were interacting on fair terms, no society would unduly restrict the opportunities faced by others. True, real-world states often take advantage of their superior bargaining power and are insensitive to the demands of fairness. ${ }^{78}$ But if they interacted on terms of reciprocity, so the reply goes, these problems would not arise and each society could be taken to be responsible for its fate.

This may be true, but it begs the question. To say that if relations between societies were generally fair, societies could be meaningfully taken to be responsible for their own fate, is to evade the issue, central to the present discussion, of what international fairness consists of. ${ }^{79}$ Moreover, if Rawls is right about the

${ }^{75}$ In so saying we are not suggesting that Rawls is a 'luck-egalitarian', but simply pointing to the centrality of considerations of responsibility in his theory of domestic justice. For discussion see Mathias Risse and Michael Blake, 'Two Models of Equality and Responsibility', Canadian Journal of Philosophy, (2008), pp. 165-99.

76 John Rawls, Political Liberalism with a New Introduction and the 'Reply to Habermas' (New York: Columbia University Press, 1996), p. 267. For discussion see Pogge, 'Rawls on International Justice', p. 250 .

77 So, for instance, Pogge argues that Rawls's own (anti-egalitarian) approach to international justice 'does not protect poor societies against skewed (and deteriorating) terms of cooperation exacted from them through the greater (and increasing) bargaining power of the affluent'. Pogge, 'Rawls on International Justice', p. 251. David Miller also expresses similar worries (though in the context of a much more sympathetic analysis of Rawls), saying that inequalities between peoples may also constitute inequalities of power, which will have a distorting effect on future terms of international cooperation'. See David Miller, 'Collective Responsibility and International Inequality in The Law of Peoples' in Rawls's Law of Peoples: A Realistic Utopia?, pp. 191-205, p. 203. In fact, Miller has recently argued that 'self-determination also gives us a reason to limit global inequality', in National Responsibility and Global Justice, p. 74, n. 22, emphasis in original.

78 David Miller and John Rawls seem to be both aware of this. See, respectively, The Law of Peoples, p. 53 and National Responsibility and Global Justice, pp. 75-6.

79 This point is forcefully made against Rawls by Simon Caney in 'Cosmopolitanism and the Law of Peoples', Journal of Political Philosophy, 10 (2002), pp. 95-123, p. 118, and by Thomas W. Pogge in 'The Incoherence between Rawls's Theories of Justice', Fordham Law Review, 72 (2004), pp. 1739-59, p. 1751. 
potentially perverse cumulative effects of individually fair interactions, it would seem that individually fair international interactions would be unlikely to generate a fair and stable international background.

\section{(iii) Poor incentives}

The worry, powerfully articulated by David Miller, ${ }^{80}$ that global egalitarian principles generate perverse incentives is a legitimate one. It is certainly possible that a system of transfers from advantaged countries or persons to less advantaged countries or persons could lead to less prudent behaviour generally, and indeed make all (or most) people worse off as a result. This concern is common also in domestic contexts, where it is often feared that redistributive policies will erode people's sense of responsibility as well as their incentives to save and invest. A global egalitarian can, however, incorporate concern with this type of 'moral hazard'.

Consider, once again, how Rawls addresses this problem in the domestic context. His second principle of justice favours institutional arrangements that improve the lowest socioeconomic position. According to this principle, transfers aimed at eliminating inequalities amongst children resulting from parental choices would have to be rejected insofar as they turned out to erode the incentives for parents to save and work hard to such an extent as to worsen the absolute socioeconomic position of the least advantaged.

This is why the second principle would allow children to bear the burdens of parental decisions insofar as this is necessary to provide adequate incentives for savings and productive work choices. Rawls's solution at the domestic level is thus both egalitarian and sensitive to the potentially damaging incentive effects of some equality-promoting policies.

Similarly, a global egalitarian can attempt to strike a balance by calling for international arrangements ensuring that countries have adequate incentives to save, invest, and make prudent policy choices while at the same time mitigating inequalities to the extent possible. There is certainly truth in the claim that global egalitarians have often neglected issues of implementation, and generally have failed to provide an account of what an incentive-compatible global egalitarian order might look like. By itself, this lacuna does not prove that such an order would be infeasible. Although they do not discredit global egalitarianism, such criticisms thus point to ways in which global egalitarian doctrines need to be further developed.

\section{Shared social meanings}

Any global egalitarian doctrine will make assessments of the extent of global inequalities focusing on one or more normatively relevant dimension(s) - for example, capabilities, life-prospects, income and wealth, respect for human rights, or a weighted combination of some or all of these and other 'goods'.

${ }^{80}$ Miller, National Responsibility and Global Justice, pp. 70-1. 
One reason some egalitarians have rejected global egalitarianism is that, absent shared social meanings, no plausible goods can be defined for the purpose of assessing relative shares. ${ }^{81}$ Whereas we can rely on shared understandings of the meanings of goods and opportunities in assessing inequalities domestically, we cannot do so internationally.

Focusing on the particular case of global equality of opportunities, David Miller states the challenge succinctly: 'if education, for example, takes different forms in different places, how can we judge whether a child in country A has better or worse opportunities than a child in country B? ${ }^{92}$ To make such assessments, we will need to adopt a particular stance with respect to the value of different opportunities, and such a stance will not be neutral between the different societies. Similar considerations would also apply to goods other than opportunities. They would apply, for instance, to Rawls's 'social primary goods' which, as he says, only make sense against the background of a liberal democratic political culture. ${ }^{83}$ Following Miller, we can refer to this as the 'metric problem'. ${ }^{84}$

The task of defining a metric for evaluating relative shares is indeed a challenging one, and there are good reasons to adopt a conception of goods that respects the autonomy and diversity of different cultures. However, these considerations do not provide decisive reasons to reject global egalitarianism (or at least those versions of global egalitarianism that are susceptible to them).

As noted by Simon Caney, this problem arises not only between but also within societies. ${ }^{85}$ Societies are often inhabited by many different cultural groups, who disagree fiercely about the value of different goods and opportunities. But most egalitarians nevertheless maintain that a society must invoke some account of the value of different goods and opportunities in making policy choices and designing social institutions.

Although there may be disagreement about which goods are most valuable, it is hard to deny the importance of adequate nutrition, clothing, shelter, certain basic freedoms, as well as social interaction, education, and participation to a decent human life. ${ }^{86}$ While not neutral, such goods are also not tied to a highly specific conception of individual advantage, and thus may be acceptable to a relatively broad range of cultural groups.

The global egalitarian can thus argue that we should try to grant people relatively equal opportunities to realise their different ways of life, by addressing inequalities in those goods (mentioned above) that are likely to be of great

${ }^{81}$ David Miller, 'Against Global Egalitarianism' and National Responsibility and Global Justice, ch. 3. A more recent statement of this type of argument is offered by Gillian Brock, 'Caney's Global Political Theory', Journal of Global Ethics, 3 (2007), sec. 1. For responses to this type of criticisms see Simon Caney, 'Cosmopolitan Justice and Equalizing Opportunities', Metaphilosophy, 32 (2001), pp. 113-34, esp. pp. 118-22 and 'Justice, Borders and the Cosmopolitan Ideal: A Reply to Two Critics', Journal of Global Ethics, 3 (2007), pp. 269-76, esp. 269-272.

${ }^{82}$ Miller, 'Against Global Egalitarianism', p. 63.

83 John Rawls, 'Kantian Constructivism in Moral Theory' (1980), in Samuel Freeman (ed.) John Rawls: Collected Papers (Cambridge, MA: Harvard University Press, 1999), pp. 303-58.

${ }^{84}$ In Miller's words, 'It is essentially the problem of saying what equality of opportunity means in a culturally plural world in which different societies will construct goods in different ways and also rank them in different ways'. See National Responsibility and Global Justice, p. 67, emphasis in original.

${ }^{85}$ Caney, 'Justice, Borders and the Cosmopolitan Ideal', p. 270.

${ }^{86} \mathrm{Cf}$. the (controversial) list of capabilities defended by Martha Nussbaum in Women and Human Development (Cambridge: Cambridge University Press, 2000), pp. 78-80. 
importance to them whatever their culture and value system may be. ${ }^{87}$ Surely there will be cases where it is not obvious whether, and to which extents, opportunities are equal across people or groups in different societies. But, as Caney notes, this does not count against the global egalitarian ideal as such. Rather, it merely points to the difficulties we encounter in specifying what equality of opportunities (or of some other good) might require at the global level. ${ }^{88}$ Of course, these difficulties might bring global egalitarians' policy-agendas closer to those of their critics, but they do not affect the egalitarian grounds on which such agendas are advocated.

\section{International pluralism}

Central to the challenge from international pluralism is the worry that an egalitarian global order would entail disrespect for those political cultures which differ from liberal ones but are decent enough to honour basic human rights. Since, in the domestic context, liberals are committed to tolerating a variety of 'reasonable' conceptions of the good, they should be similarly prepared to tolerate political cultures which are not fully liberal in the international one.

This analogy, famously utilised by Rawls, ${ }^{89}$ has been widely criticised for containing a 'double standard' of reasonableness. ${ }^{90}$ Within the domestic arena, reasonableness is typically defined in terms of 'compatibility with principles of justice'. Why should the criterion of reasonableness we employ internationally differ from the one we adopt domestically? In answer to this question, Rawls says 'whenever the scope of toleration is extended: The criteria of reasonableness are relaxed', ${ }^{11}$ but the reason why this is so remains unclear. ${ }^{92}$ There are at least two possibilities here. Either the relaxation of the criteria of reasonableness is principled, or it is instrumental. Both options, we argue, have unpalatable consequences for critics of global egalitarianism.

Let us begin with 'instrumental relaxation'. ${ }^{93}$ Here, the idea is that we should not advocate global egalitarianism worldwide as this would lead to counterproductive consequences. Even if an egalitarian global order would be the moral

${ }^{87}$ As Leif Wenar has recently pointed out, the egalitarian can say that our goal should be to leave aside the more difficult cases and 'make individuals equal in ways they clearly and uncontroversially are now not'. See Leif Wenar, 'Humanity and Equality in the Work of David Miller', Critical Review of International Social and Political Philosophy, 11 (2008) pp. 401-11, p. 403.

${ }^{88}$ Caney, 'Justice, Borders and The Cosmopolitan Ideal', p. 271.

89 Rawls, The Law of Peoples, pp. 59-60.

90 This critique has been advanced, for instance, by Kok-Chor Tan, 'Liberal Toleration in Rawls's Law of Peoples', Ethics, 108 (1998), pp. 275-95, at pp. 282ff., Andrew Kuper, 'Rawlsian Global Justice: Beyond The Law of Peoples to a Cosmopolitan Law of Persons', Political Theory, 28 (2000), pp. 640-74, at pp. 648-53, Pogge, 'Rawls on International Justice', at p. 249 and 'An Egalitarian Law of Peoples', Philosophy and Public Affairs, 23 (1994), pp. 195-224, at. pp. 214-7. See also Caney, 'Cosmopolitanism and the Law of Peoples', pp. 100-103 and pp. 105-6, Beitz, 'Rawls's Law of Peoples', pp. 683-6, Allen Buchanan, 'Rawls's Law of Peoples: Rules for a Vanished Westphalian World', Ethics, 110 (2000), pp. 697-721, at pp. 718-9, and Saladin Meckled-Garcia, 'International Justice, Human Rights and Neutrality', Res Publica, 10 (2004), pp. 153-74, at pp. 160-3.

${ }^{91}$ Rawls, 'The Law of Peoples', (1993), in Samuel Freeman (ed.), John Rawls: Collected Papers, (Cambridge, MA: Harvard University Press, 1999), pp. 529-64, p. 561.

92 See Tan, 'Liberal Toleration', pp. 282-4 for discussion.

93 Similar suggestions are made, for instance, by Henry Shue, 'Rawls and the Outlaws', Politics, Philosophy \& Economics, 1 (2002), pp. 307-23, p. 311 and Pogge, 'The Incoherence between Rawls's Theories of Justice', p. 1758. 
optimum, we have to aim at a second best in order to accommodate non-liberal (yet decent) political communities. Doing otherwise, would increase international tensions and render the prospects of a global egalitarian order even more remote. ${ }^{94}$

This line of argument has some plausibility; however, we need not examine it in detail for the present purposes. This is because, recall, global egalitarians hold that a concern with equality applies to the international arena as a matter of fundamental principle of justice. Such a commitment is presupposed, not denied, by 'instrumental relaxation'. At the level of fundamental principle, global egalitarianism remains unchallenged.

Let us then turn to 'principled relaxation'. As it should be obvious by now, unlike instrumental relaxation, principled relaxation holds that we should reject global egalitarianism as a matter of fundamental principle because global egalitarian standards cannot be justified. On this reading, it is reasonable for the inhabitants of non-liberal (yet decent) societies to embrace an illiberal political outlook, because liberals have no way of proving that they are wrong in doing so. ${ }^{95}$ Liberals cannot point to oppression (the regimes are decent) or other factors to discredit the genuine nature of these people's illiberal beliefs. ${ }^{96}$

In light of this, liberals must lower their justificatory ambitions and consider as reasonable all of those doctrines which, at the political level, support regime-types which might be said to allow individuals sufficient freedom to develop their own considered convictions. In other words, so long as such regimes are respectful of human rights and other minimal standards of justice, they cannot be objected to on grounds of unreasonableness.

If sound, this argument would seem to bring unwelcome consequences for all egalitarians, casting doubt on the justifiability of egalitarianism not only at the international, but also at the domestic level. Indeed, why should non-liberal (yet decent) minorities living within liberal borders be governed by liberal principles, when it is legitimate for decent peoples outside liberal borders to disregard them? ${ }^{97}$ To allow for such a disanalogy, is to make the applicability of moral principles dependent of morally arbitrary factors - such as one's country of birth. Once it is conceded that, internationally, some illiberal (yet decent) cultures are the product of the 'burdens of human judgment', the same concession (and its normative implications) cannot be easily denied at the domestic level. This means that the challenge from pluralism may be inconsistent with being an egalitarian critic of global egalitarianism.

\section{VIII. (In)feasibility}

Global egalitarian proposals are often accused of being infeasible. Driving this critique is the thought that, since 'ought implies can', any plausible normative ideal

94 Rawls, The Law of Peoples, p. 62.

95 This reading of Rawls's The Law of Peoples is forcefully defended by David A. Reidy in his, 'Rawls on International Justice: A Defense', Political Theory, 32 (2004), pp. 291-319, pp. 306-16. See also Freeman, 'The Law of Peoples', p. 50.

${ }^{96}$ For a description of the features of decent societies see Rawls see The Law of Peoples, pp. 64-8.

97 This is the main thrust of the criticisms raised against The Law of Peoples by the critics mentioned at footnote 90 . 
must fall within the limits of human possibility. The feasibility in question is not just a matter of immediate realisability, but rather one of compatibility with the limits imposed by our best understanding of human nature and social institutions. ${ }^{98}$ As John Rawls puts it, philosophers must argue 'as best [they] can that the social world [they] envision is feasible and might actually exist, if not now at some future time under happier circumstances'. ${ }^{99}$

Within the specific domain of political morality, the feasibility constraint becomes further qualified in terms of institutional feasibility. ${ }^{100}$ On this view, an imperative such as 'You ought to design a society for angels' would be immediately rejected as false: since no set of institutions can turn human beings into angels, there can be no genuine duty to create one.

Simply put, the feasibility critique claims that a global egalitarian order is akin to a society of angels: it exceeds human institutional possibilities and thus cannot count as a valid normative ideal. This critique admits of two interpretations. The first is that the global egalitarian ideal is infeasible tout court: there can be no stable set of institutions with the capacity to promote global equality. The second holds that, even if such a set of institutions were feasible, a global egalitarian world would still be 'morally inaccessible' from the status quo, since the moral costs of moving towards that world would be far too high. ${ }^{101}$ While the first version of this critique focuses on the realisability of the end-state global egalitarian ideal, the second focuses on the moral costs of the transition from the world as it is, to the world as it would be under such an ideal. We briefly examine each version of the critique in turn. ${ }^{102}$

The argument from infeasibility is often alluded to in support of anti-global egalitarian proposals. One of its most articulate formulations is offered by John Rawls, who extensively discusses psychological and sociological constraints on the realisation of normative ideals. In particular, he notes that only an intense process of socialisation and awareness of participating in a 'common enterprise', such as those characterising fellow-citizens, can motivate persons' continued support to a permanent scheme of economic redistribution. ${ }^{103}$

If Rawls is right, the prospects of realising global egalitarian justice depend on the possibility of the existence of an analogous 'common enterprise' at a global level. Could such a state of affairs ever come into being? Rawls, for one, answers with scepticism. A process of socialisation as intense as that taking place within domestic societies, he observes, can hardly occur globally. On his view, a global egalitarian distributive scheme could not count on the stable voluntary support of the world's population, but could only be implemented through sheer coercion. A

${ }^{98}$ We discussed the implausible implications of feasibility understood as 'realisability in the here and now' in the section on agency.

${ }^{99}$ Rawls, The Law of Peoples, p. 12.

${ }^{100}$ See Harry Brighouse, Justice (Cambridge: Polity Press, 2004), ch. 2.

${ }^{101} \mathrm{We}$ borrow the concept of moral accessibility from Allen Buchanan, Justice, Legitimacy, and Self-Determination (Oxford: Oxford University Press, 2004), p. 61. See also Juha Räikkä, 'The Feasibility Condition in Political Theory', Journal of Political Philosophy, 6 (1998), pp. 27-40. Räikkä maintains that, in assessing the plausibility of an ideal theory, we should take into account the 'moral costs of changeover', p. 35.

${ }^{102}$ For discussion of these points see also Valentini, 'Global Justice', ch. 2, and 'The Law of Peoples between Ideal and Non-ideal Theory' (University College London: MA thesis, 2005).

${ }^{103}$ Rawls, The Law of Peoples, p. 112, n. 44. This point is noted and discussed by Beitz in 'Rawls's Law of Peoples', pp. 681-2. 
global distributive scheme, that is, would require the establishment of a world state and this, in Rawls's own words, would 'either be a global despotism or else would rule over a fragile empire torn by frequent civil strife'. ${ }^{104}$ In short, a liberal egalitarian global order is impossible: it is incompatible with human institutional and psychological limits.

A forceful statement of the second kind of feasibility critique has been recently offered by Thomas Nagel, who suggests that a world government would be required to implement egalitarian justice and that, in all likelihood, such government would be preceded by the establishment of a 'global Leviathan'. Noticing that, historically, most democratic institutions arose from a process started with the formation of illegitimate concentrations of coercive power, Nagel alarmingly predicts that 'the most likely path toward some version of global justice is through the creation of patently unjust and illegitimate global structures of power that are tolerable to the interests of the most powerful current nationstates'. ${ }^{105}$ The idea is that only at a later stage would demand for legitimacy be pressed against such an overarching authority and hopefully global justice established. If this suggestion is correct, the moral costs of the transition from where we are, to a just global egalitarian order, would turn out be far too high according to the very moral standards defended by global egalitarians.

Does the feasibility critique, in either of its two versions, succeed in showing that global egalitarianism is implausible? In what follows we will offer two arguments in support of the claim that it does not. ${ }^{106}$

First, feasibility critiques of both types typically make the dubious assumption that global egalitarian aims could best (or only) be promoted through the establishment of a world state. This, however, need not be the case: Sovereignty need not be absolute and power entirely concentrated in the hands of one agent. ${ }^{107}$ The division of powers and competences within contemporary democratic governments, and particularly within federal states, points toward the practical possibility of sovereignty without absoluteness. Moreover, if such critics are correct about the risks of creating a global state, this would only show that a globalised difference principle or some other egalitarian principle would not select the global state as its favoured institutional means. The principle would instead favour whatever scheme best realised its distributive standard.

Even if a world state turned out to be impossible to bring about or maintain, or had the seriously counterproductive effects envisioned by its critics, this would not count against global egalitarian ideals any more than an economic argument showing (however improbably) that the least advantaged fared better under a laissez-faire scheme than in a welfare state would count against Rawls's domestic difference principle. In the latter case, the laissez-faire scheme would satisfy the

\footnotetext{
${ }^{104}$ Rawls, The Law of Peoples, p. 36. See also Immanuel Kant, Perpetual Peace, in H. Reiss (ed.), Kant's Political Writings (London: Cambridge University Press, 1970).

${ }^{105}$ Nagel, 'The Problem of Global Justice', p. 146.

${ }^{106}$ These issues have been explored illuminatingly and at length by Beitz in Political Theory and International Relations, pp. 156-7. Our argument here is very much in line with his.

107 Thomas W. Pogge, 'Cosmopolitanism and Sovereignty', Ethics, 103 (1992), pp. 48-75. See also Andrew Kuper, who sketches a system of 'functional plural sovereignty', in Kuper 'Rawlsian Global Justice', and more fully in his Democracy beyond Borders: Justice and Representation in Global Institutions (Oxford: Oxford University Press, 2004).
} 
difference principle, and in the former case, the global egalitarian distributive standard would select whichever institutional arrangement satisfied it.

In addition, there are no grounds for ruling out a priori the possibility for individuals to develop the necessary motivational resources to support global egalitarian institutions. ${ }^{108}$ Human motivation is deeply influenced and shaped by the particular social institutions under which people conduct their lives, and it is at least possible that, in an increasingly globalised world, citizens of different countries will come to see themselves as citizens of the same 'cosmopolis'. ${ }^{109}$

Consider the cases of Europe and the US, where local allegiances intertwine with national, if not 'continental' ones. Perhaps, centuries before the formation of these federal political units, such complex motivational baggage would have been unthinkable, but that does not mean that it was impossible - that is, ruled out by our best understanding of human nature. In fact, considering the powerful intuitions in support of global egalitarianism, it should not be too hard for a coherent domestic liberal egalitarian to be motivated to support a global regime capable of realising global egalitarian demands.

The latter observation also allows us to challenge the alleged moral inaccessibility of an egalitarian world order. Recall, this was premised on the claim that the only path from the status quo to global egalitarianism would be undemocratic. Once again, this need not be the case: a global egalitarian order peacefully emerging from a global civil society is equally conceivable. Both a 'top-down', and a 'bottom-up' path to global equality seem genuine possibilities and it is hard, in fact probably impossible, to determine which one (if any) would be more likely to occur.

This last remark is revelatory of the tentative nature of feasibility arguments. Unless one focuses on the extreme case of a duty to build a society designed for angels, arguments in favour and against the feasibility of certain social arrangements are bound to be highly speculative. In line with this, we have shown that, if one can plausibly speculate that a global egalitarian order is not feasible, one can also equally speculate that it is.

In short, quarrels about feasibility are, except for extreme and uninteresting cases, ultimately inconclusive. Theorists can quarrel almost infinitely, but they will hardly be able to convincingly refute each others' claims. In the face of such reasonable disagreement about the feasibility of principles, it seems unreasonable simply to reject them. In this sense the position of the political theorist is quite different from that of the politician or institutional designer, who may indeed have reason not to implement reforms unless they have very good grounds for believing that they will produce desirable (or at the very least not harmful) outcomes.

Second, unless one takes the absolutist view that justice is an all-or-nothing matter, that either a social ideal is fully realisable or it is useless, the alleged infeasibility (unless extreme, as in the society of angels example) of an ideal should not count against it. ${ }^{110}$ Indeed, speaking of the 'unrealisability' of principles often

${ }^{108}$ For a 'state-centred' account of how this might be possible see Lea L. Ypi, 'Statist Cosmopolitanism', Journal of Political Philosophy, 16 (2008), pp. 48-71.

${ }^{109}$ On the capacity of institutions to shape persons' character see Joshua Cohen, 'Taking People as They Are?', Philosophy and Public Affairs, 30 (2001), pp. 363-86.

${ }^{110}$ Arash Abizadeh makes a similar point in his discussion of the feasibility of a just global basic structure in his 'Cooperation, Pervasive Impact, and Coercion', pp. 340-1. 
makes little sense. When principles are comparative, as they are, for instance, in Rawls's theory of domestic justice, there will always be at least one set of institutional arrangements that satisfies them. Rawls's theory, for instance, demands that, among the feasible institutional arrangements, we choose the one which best fulfils his two principles of justice. ${ }^{111}$

Even when principles are non-comparative, we can remain agnostic about whether a social ideal is fully realisable - in fact, given what we have just said, agnosticism would seem to be the most intellectually rigorous stance to take - and still act 'in the spirit' of that ideal. ${ }^{112}$ This requires careful exercise of judgement - including judgement as to whether directly aiming at the realisation of the ideal is likely to generate morally objectionable outcomes. ${ }^{113}$ For instance, the direct imposition of democratic institutions in a society which lacks a democratic culture will probably result in more harm than good. However, from this it does not follow that democracy is not, ultimately, a worthy ideal. ${ }^{114}$ In other words, it is one thing to say that the realisation of an ideal (be it partial or complete) requires careful judgement, and quite another to say that we should get rid of the ideal altogether, as the (in)feasibility critique would require. ${ }^{115}$

In light of the above, we conclude that the (in)feasibility critique fails to offer a conclusive refutation of global egalitarianism. Unless critics convincingly argue that global egalitarian ideals are exactly like societies of angels - that is in principle unrealisable - the normative attractiveness of such ideals remains undamaged by such critiques. ${ }^{116}$

\section{Conclusion}

In this article we have discussed seven egalitarian critiques of global egalitarianism and showed that they do not provide convincing arguments against extending principles of egalitarian justice from the domestic to the global arena. We have not offered a positive defence of global egalitarian doctrines, but only argued that some prominent recent critiques of such doctrines do not give us sufficient reason to reject them.

This is not to say that the critics' objections leave global egalitarianism completely unaffected. However, instead of proving that global egalitarianism is implausible, such objections reveal that it is problematically incomplete. Global

${ }^{111}$ In a similar vein, Amartya Sen distinguishes between what he calls 'transcendental' and 'purely comparative' approaches to justice. See Sen, 'What Do We Want from a Theory of Justice?', The Journal of Philosophy, 103 (2006), pp. 215-38. Sen maintains (incorrectly in our view) that Rawls's principles are 'transcendental'.

112 This suggestion is made by Michael Phillips in his 'Reflections on the Transition from Ideal to Non-Ideal Theory', Noûs, 19 (1985), 551-70, esp. p. 557.

${ }^{113}$ See Robert Goodin's helpful discussion of second-best theories in 'Political Ideals and Political Practice'.

${ }^{114}$ For an interesting discussion of the forceful imposition of democracy see Allen Buchanan, 'Institutionalizing the Just War', Philosophy and Public Affairs, 34 (2006), pp. 2-38.

${ }^{115}$ See Charles R. Beitz's remarks in 'Cosmopolitan Ideals and National Sentiment', The Journal of Philosophy, 80 (1983), pp. 591-600, p. 595.

${ }^{116}$ For further discussion of the relation between ideal theory and political practice in theorising about global justice see Charles R. Beitz, 'Justice and International Relations', Philosophy and Public Affairs, 4 (1975), pp. 360-89, esp. pp. 383-9. 
egalitarian approaches need to be further developed if they are to establish themselves as persuasive normative doctrines. For instance, agency-based and feasibility-based arguments point to the need for global egalitarians to be more explicit about the practical implications of their views. Moreover, global egalitarians have yet to offer a convincing account of how their theories would handle concerns of national responsibility and international pluralism.

In our discussion we have only sketched how global egalitarians might begin to address such concerns, and nothing in what we have said guarantees that they will succeed in doing so. Our aim in this article has been to show that, instead of discouraging global egalitarians, these challenges should prompt them to further develop the outlooks they defend. 